\title{
Consistent seasonal snow cover depth and duration variability over the Western Himalayas (WH)
}

\author{
Dan Singh*, Vikas Juyal and Vikas Sharma \\ Research and Development Centre, Snow and Avalanche Study Establishment, Sector 37 A, \\ Chandigarh 160 036, India. \\ *Corresponding author.e-mail: dan_@rediffmail.com
}

Precipitation in solid form, i.e., snow, during winter season over the Western Himalayas (WH) leads to the build-up of seasonal snow cover. Seasonal snow cover build-up (snow cover depth and duration) largely depends on atmospheric variables such as temperature, precipitation, radiation, wind, etc. Integrated (combined) influence of atmospheric variables on seasonal snow cover gets reflected in terms of spatial and temporal variability in seasonal snow cover build-up pattern. Hence spatial and temporal variability of seasonal snow cover build-up can serve as a good indicator of climate change in high altitude mountainous regions like the WH. Consistent seasonal snow cover depth and duration, delay days and early melt days of consistent seasonal snow cover at 11 stations spread across different mountain ranges over the WH were analyzed. Mean, maximum and percentiles (25th, 50th, 75th, 90th and 95th) of consistent seasonal snow cover depth and duration show decline over the WH in the recent past 2-3 decades. Consistent seasonal snow cover is found to melt early and snow cover build-up pattern is found to show changes over the WH. Decline in consistent seasonal snow cover depth, duration and changing snow cover buildup pattern over the WH in recent decades indicate that WH has undergone considerable climate change and winter weather patterns are changing in the WH.

\section{Introduction}

Mountainous regions around the globe are storehouses of biodiversity, global ecosystem and global hydrological cycle (Robinson et al. 1993; Beniston et al. 1997; Beniston 2003). They are sensitive indicators of climatic changes and are highly vulnerable to climatic changes (Beniston et al. 1997; Zhang 2007; Kang et al. 2010). The Himalayas, the Alps, the Rockies, the Andes, etc., play an important role in shaping regional as well as global scale weather and climate systems (Aguado 1990; Robinson et al. 1993; Beniston et al. 1997; Roe 2005). Glaciers and seasonal snow cover regulate weather and climate, preserve ecosystem and serve as sources of fresh water for many perennial river systems (Dettinger and Cayan 1995; Fowler and Archer 2005;
Kulkarni et al. 2007; Bhutiyani et al. 2008; Rechid et al. 2009; Thayyen and Gergan 2009). Glaciers and snow cover continuously interact with the overlying atmosphere; hence, these are largely affected by atmospheric variables such as air temperature, precipitation, radiation, wind, pollution, etc. Mass and energy balances, arial extent, depth, duration, etc., of glaciers and seasonal snow cover have been modelled, studied and analysed to study climatic changes (Walsh et al. 1982; Robinson et al. 1993; Beniston 1997; Brown and Braaten 1998; Martin and Durand 1998; Kulkarni and Bahuguna 2002; Kulkarni et al. 2005; Zhang 2007; Rupper and Roe 2008; Chaujar 2009).

Precipitation in solid form, i.e., snow, during the winter season (November to April) leads to extensive build-up of a seasonal snow cover over the

Keywords. Temperature; precipitation; seasonal snow cover depth and duration. 
Western Himalayas (WH) (Dimri and Das 2011; Singh et al. 2015). Seasonal snow cover over the Himalayas is found to have an important role in modulating Indian Summer Monsoon Rainfall (ISMR) and regulating regional as well as global scale weather and climate (Dey et al. 1985; Wu and Qian 2003; Bollasina and Benedict 2004; Feng and $\mathrm{Hu}$ 2005; Zhang 2007; Rechid et al. 2009). Systematic study and understanding of spatial and temporal variability of seasonal snow cover depth and duration over the WH are extremely important for climatic changes, weather and climate modelling, understanding its role on ISMR, management of water resources, etc., in the Indian subcontinent. Decline in seasonal snow cover depth and snow cover days, in the $\mathrm{WH}$, in the recent decades have been reported (Singh et al. 2012, 2015). However, these studies do not provide details on spatial and temporal variability of consistent seasonal snow cover depth and duration, maximum seasonal snow cover depth, delay days, early melt days and changing pattern of consistent seasonal snow cover build-up in the WH.

The present study was undertaken to examine the parameters mentioned above at 11 stations spread across the Shamshawari, the Pir Panjal and the Great Himalayan Ranges, in the WH. This study can help to get a better insight on the build-up of consistent seasonal snow cover and the changing pattern of snow cover build-up, over the WH in the larger perspective of global warming. Results of this study can be useful for weather and climate modelling, hydrological modelling and applications, climate change impacts assessment, water resources management, planning and decision making for various socio-economic developments, etc., in the western Himalayan region.

\section{Study area and data}

Snow cover depth from 11 stations spread across the Shamshawari, the Pir Panjal and the Great Himalayan Ranges, in the WH in India, were taken for this study, and the stations are shown in figure 1. These stations fall in the high altitude mountainous regions of the north Indian states of Himachal Pradesh (HP) and Jammu and Kashmir $(\mathrm{J} \& \mathrm{~K})$. Snow cover depth data collected daily at 0300 UTC at each station were obtained from the data archive of the Snow and Avalanche Study Establishment (SASE), Chandigarh, India (Bhutiyani et al. 2007; Singh et al. 2015). Consistent seasonal snow cover length (duration) (CSSL), delay days in the build-up of consistent snow cover $\left(\mathrm{DD}^{\mathrm{css} d}\right)$ and early melt days of consistent seasonal snow cover $\left(\mathrm{ED}^{\mathrm{css}}\right)$ at each station for a winter were derived based on seasonal snow cover depth. Consistent seasonal snow cover is defined as snow cover which lasts for the maximum number of days for a winter. CSSL for a winter at each station is defined as the cumulative number of days for which consistent seasonal snow cover exists. DD ${ }^{\text {cssd }}$ is defined as the cumulative number of days from the start date of winter (1st November) till the day when consistent seasonal snow cover builds and $\mathrm{ED}^{\mathrm{cssd}}$ is defined as the cumulative number of days from the date of melt of consistent seasonal snow cover till end date of winter season (30 April). Details of the variables taken for this analysis are

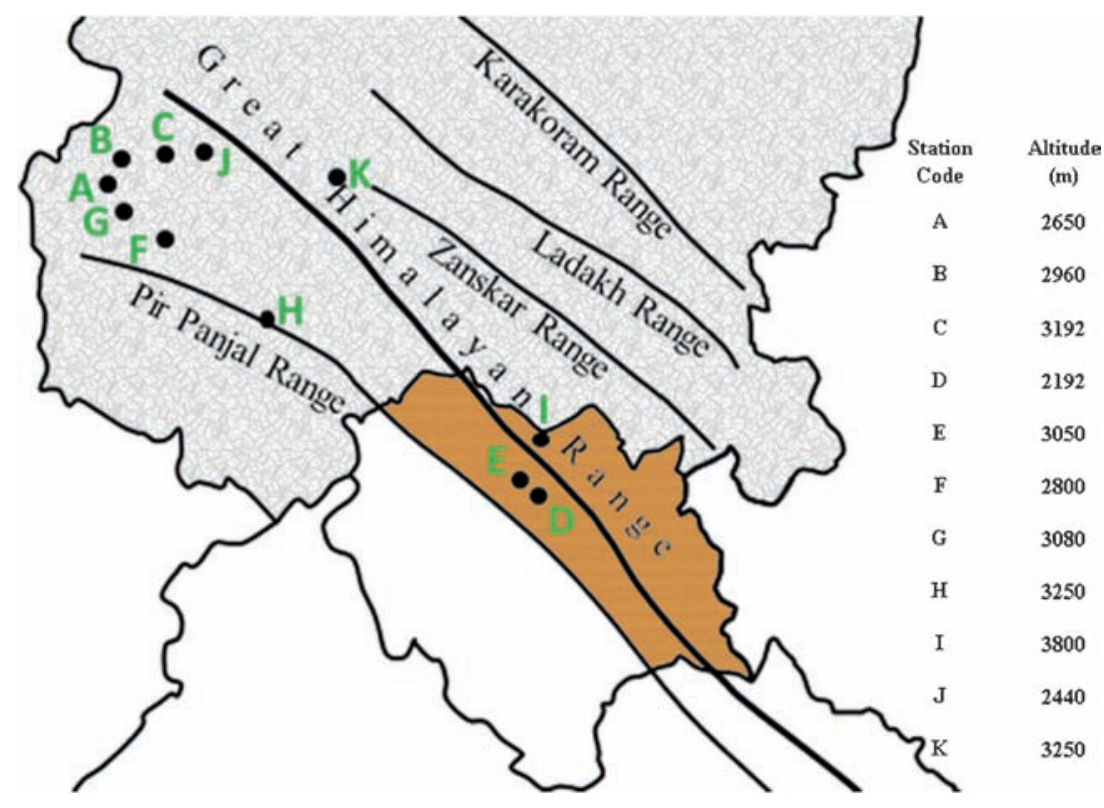

Figure 1. Stations in different mountain ranges over the Western Himalayas (WH). 
given in table 1 . It is seen that more than $95 \%$ records of seasonal snow cover depth fall within the range of mean \pm 3 standard deviation and data on snow cover depth were found to be suitable for present analysis.

Data on snow cover depth for a few winters are not available strictly from 1st November to 30th April. The unavailable data corresponds to a few days of either November (early winter) or April (late winter). This may affect computation of $\mathrm{DD}^{\mathrm{cssd}}$ and $\mathrm{ED}^{\mathrm{cssd}}$, and these are determined based on data on snow cover depth of nearby stations in the same climatic regime (table 2 ).

Data on snow cover depth at stations D and $\mathrm{E}$ are available for consecutive and continuous winters. It is missing (or not available for complete winter period) for one winter at 7 stations, two and three winters at stations $\mathrm{C}$ and I, respectively (table 2). Auto-regressive Moving Average (ARIMA) models of order $1,0,1$ were used to forecast the variables listed in table 1 for missing winters. ARIMA $(1,0,1)$ models were used to forecast missing data from both ends of the time series using the forecast package available with $\mathrm{R}$ system for statistical computations (https:/CRAN.
R-project.org). Mean value of forecasts from both ends of time series was used to fill missing data gaps. Filled missing data may not affect time series of any variable significantly (in the absence of actual data). This is because forecasts are made from both ends of the time series and these are made for one winter only at most of the stations ( 7 out of 9 stations). This helped us to make a continuous time series of variables, listed in table 1 , for further analysis. Climatology of consistent seasonal snow cover depth and duration, maximum depth of consistent seasonal snow cover, delay days and early melt days of consistent seasonal snow cover is given in table 2. The large differences in the values of these parameters at different stations show that seasonal snow cover build-up exhibits large spatial and temporal variability, and displays strong regional character over the WH (table 2).

\section{Methodology}

Seasonal snow cover build-up for a winter season is broadly described by snow cover depth and its duration. Variability in winter weather patterns

Table 1. List of variables and their abbreviations.

\begin{tabular}{|c|c|c|}
\hline S. no. & Variable (unit) & Abbreviation \\
\hline 1. & Consistent seasonal snow cover depth $(\mathrm{cm})$ & CSSD \\
\hline 2. & $\begin{array}{l}25 \mathrm{th}, 50 \mathrm{th}, 75 \mathrm{th}, 90 \mathrm{th} \text { and } 95 \mathrm{th} \text { percentiles and } \\
\text { maximum value of CSSD }(\mathrm{cm})\end{array}$ & $25^{\mathrm{cssd}}, 50^{\mathrm{cssd}}, 75^{\mathrm{cssd}}, 90^{\mathrm{cssd}}, 95^{\mathrm{cssd}}$, and $\mathrm{MX}^{\mathrm{cssd}}$ \\
\hline 3. & Consistent seasonal snow cover length (days) & CSSL \\
\hline 4. & $25 \mathrm{th}, 50 \mathrm{th}, 75 \mathrm{th}, 90 \mathrm{th}$ and $95 \mathrm{th}$ percentiles of CSSL (days) & $25^{\mathrm{cssl}}, 50^{\mathrm{css} l}, 75^{\mathrm{cssl}}, 90^{\mathrm{cssl}}$ and $95^{\mathrm{cssl}}$ \\
\hline 5. & Number of days when CSSD attains maximum value (days) & $\mathrm{MX}^{\mathrm{cssl}}$ \\
\hline 6. & Delay days in build-up of consistent seasonal snow cover (days) & $\mathrm{DD}^{\mathrm{cssd}}$ \\
\hline 7. & Early melt days of consistent seasonal snow cover (days) & $\mathrm{ED}^{\mathrm{cssd}}$ \\
\hline
\end{tabular}

Table 2. Climatology of consistent seasonal snow cover depth (CSSD), consistent seasonal snow cover length (CSSL), delay days (DD ${ }^{\text {cssd }}$ ) and early melt days (ED ${ }^{\text {cssd }}$ ) of CSSD; maximum depth of CSSD (MX ${ }^{\text {cssd }}$ ) and days when CSSD attains maximum depth $\left(\mathrm{MX}^{\mathrm{cssl}}\right)$ at 11 stations spread across different mountain ranges over the Western Himalayas (WH) (Mtn Range = Mountain range, $S$ range = the Shamshawari Range, $P$ range = the Pir Panjal Range, $G$ Range = the Great Himalayan Range; Stn = stations; Alt $=$ Altitude $\mu=$ mean, $\sigma=$ standard deviation).

\begin{tabular}{|c|c|c|c|c|c|c|c|c|c|c|c|c|c|}
\hline \multirow[b]{2}{*}{ Mountain range } & \multirow[b]{2}{*}{ Stn } & \multirow{2}{*}{$\begin{array}{l}\text { Alt } \\
(\mathrm{m})\end{array}$} & \multirow{2}{*}{$\begin{array}{l}\text { Winter data length } \\
\text { (No. of winters) }\end{array}$} & \multicolumn{2}{|c|}{ CSSD } & \multicolumn{2}{|c|}{ CSSL } & \multicolumn{2}{|c|}{$\mathrm{DD}^{\mathrm{cssd}}$} & \multicolumn{2}{|c|}{$\mathrm{EM}^{\mathrm{cssd}}$} & \multicolumn{2}{|c|}{$\mathrm{MX}^{\mathrm{cssd}}$} \\
\hline & & & & $\mu$ & $\sigma$ & $\mu$ & $\sigma$ & $\mu$ & $\sigma$ & $\mu$ & $\sigma$ & $\mu$ & $\sigma$ \\
\hline \multirow[t]{3}{*}{$\mathrm{S}$ range $(\mathrm{J} \& \mathrm{~K})$} & A & 2650 & $1991-2013(23)$ & 104.4 & 26.9 & 123.7 & 23.9 & 43.9 & 19.2 & 14.2 & 14.9 & 232.1 & 62.7 \\
\hline & $\mathrm{B}$ & 2960 & $1992-2013(22)$ & 120.9 & 35.2 & 121.7 & 28.7 & 49.3 & 21.9 & 10.2 & 19.0 & 256.5 & 73.1 \\
\hline & $\mathrm{C}$ & 3192 & $1992-2013(22)$ & 123.3 & 34.8 & 135.1 & 17.9 & 41.0 & 19.6 & 4.8 & 8.6 & 245.8 & 61.3 \\
\hline \multirow[t]{3}{*}{$\mathrm{P}$ range $(\mathrm{J} \& \mathrm{~K})$} & $\mathrm{F}$ & 2800 & $1987-2013(27)$ & 82.1 & 27.5 & 126.2 & 18.1 & 39.8 & 15.9 & 15.3 & 13.1 & 183.7 & 50.7 \\
\hline & $\mathrm{G}$ & 3080 & $1987-2013(27)$ & 128.5 & 41.2 & 125.3 & 30.7 & 48.5 & 23.2 & 7.6 & 13.4 & 269.5 & 93.8 \\
\hline & $\mathrm{H}$ & 3250 & 1995-2013 (19) & 50.4 & 16.8 & 99.3 & 33.7 & 49.9 & 20.8 & 32.0 & 22.8 & 237.0 & 121.0 \\
\hline \multirow[t]{2}{*}{ G range $(J \& K)$} & $\mathrm{J}$ & 2440 & $1987-2013(27)$ & 98.9 & 31.4 & 133.1 & 21.1 & 35.8 & 18.1 & 12.7 & 11.8 & 212.4 & 58.5 \\
\hline & $\mathrm{K}$ & 3250 & 1989-2013 (25) & 61.2 & 34.5 & 126.0 & 23.6 & 39.5 & 19.1 & 16.0 & 13.5 & 137.7 & 65.7 \\
\hline \multirow[t]{2}{*}{$\mathrm{P}$ range $(\mathrm{HP})$} & $\mathrm{D}$ & 2192 & 1979-2013 (35) & 29.5 & 13.6 & 27.9 & 16.2 & 84.3 & 20.7 & 69.1 & 19.7 & 72.7 & 32.3 \\
\hline & $\mathrm{E}$ & 3050 & $1989-2013(25)$ & 122.2 & 44.8 & 123.0 & 28.4 & 47.9 & 21.1 & 10.4 & 13.5 & 279.8 & 84.9 \\
\hline $\mathrm{G}$ range $(\mathrm{HP})$ & I & 3800 & 1983-2013 (31) & 94.1 & 27.0 & 140.1 & 22.1 & 39.5 & 23.2 & 2.2 & 5.0 & 184.3 & 56.6 \\
\hline
\end{tabular}


(precipitation, temperature, wind, etc.), topography and high persistence of snow cover depth leads to large spatial and temporal variability in snow cover build-up pattern at local and regional scales over the WH. Changing weather patterns like increasing air temperatures (maximum, minimum and ambient temperature), decreasing precipitation amount, increasing variability in Western Disturbances (WDs), etc., under the influence of global warming may have influenced the seasonal snow cover build-up pattern over the WH in recent decades (Bhutiyani et al. 2007; Kumar et al. 2010; Dimri and Das 2011; Madhura et al. 2014; Singh et al. 2015). This can be studied by comparing seasonal snow cover build-up patterns of different winter seasons. However, it is an extremely difficult and tedious task to compare the snow cover build-up pattern of individual winters for long length data series. A reasonable approach to handle such kind of problems is to compare the mean seasonal snow cover build-up pattern of fixed number of consecutive winters for a given time series. Mean seasonal snow cover depth time series for each day of a winter based on 10 consecutive winters and rest of the winters are computed at station E (altitude $3050 \mathrm{~m}$ msl) and station J (2440 $\mathrm{m}$ msl) in the Pir Panjal and the Great Himalayan Ranges of the WH. Decadal and rest of the winters mean seasonal snow cover build-up patterns were derived at both stations. This was done to get an idea of whether the seasonal snow cover build pattern shows temporal variability in recent decades over the WH. Data on snow cover depth at station E are available for consecutive and continuous winters. However, data on snow cover depth at station $\mathrm{J}$ for few days of a winter are missing, and the winter with missing data on snow cover depth was not considered for deriving mean snow cover build-up pattern at station J. Decadal mean seasonal snow cover depths were found to show decline at stations $\mathrm{E}$ and $\mathrm{J}$ in the recent decades (figures 2 and 3). Decadal mean snow cover depth was found to be lowest for the decade 1999-2007 at station E and the decade 1998-2007 at station $\mathrm{J}$, in the Pir Panjal and Great Himalayan Ranges, respectively, over the WH (figures 2 and 3). Snow cover depth was found to be the highest for the decade 1989-1998 and the decade 1987-1997 at stations E and J, respectively. Decadal seasonal snow cover build-up patterns were found to be similar

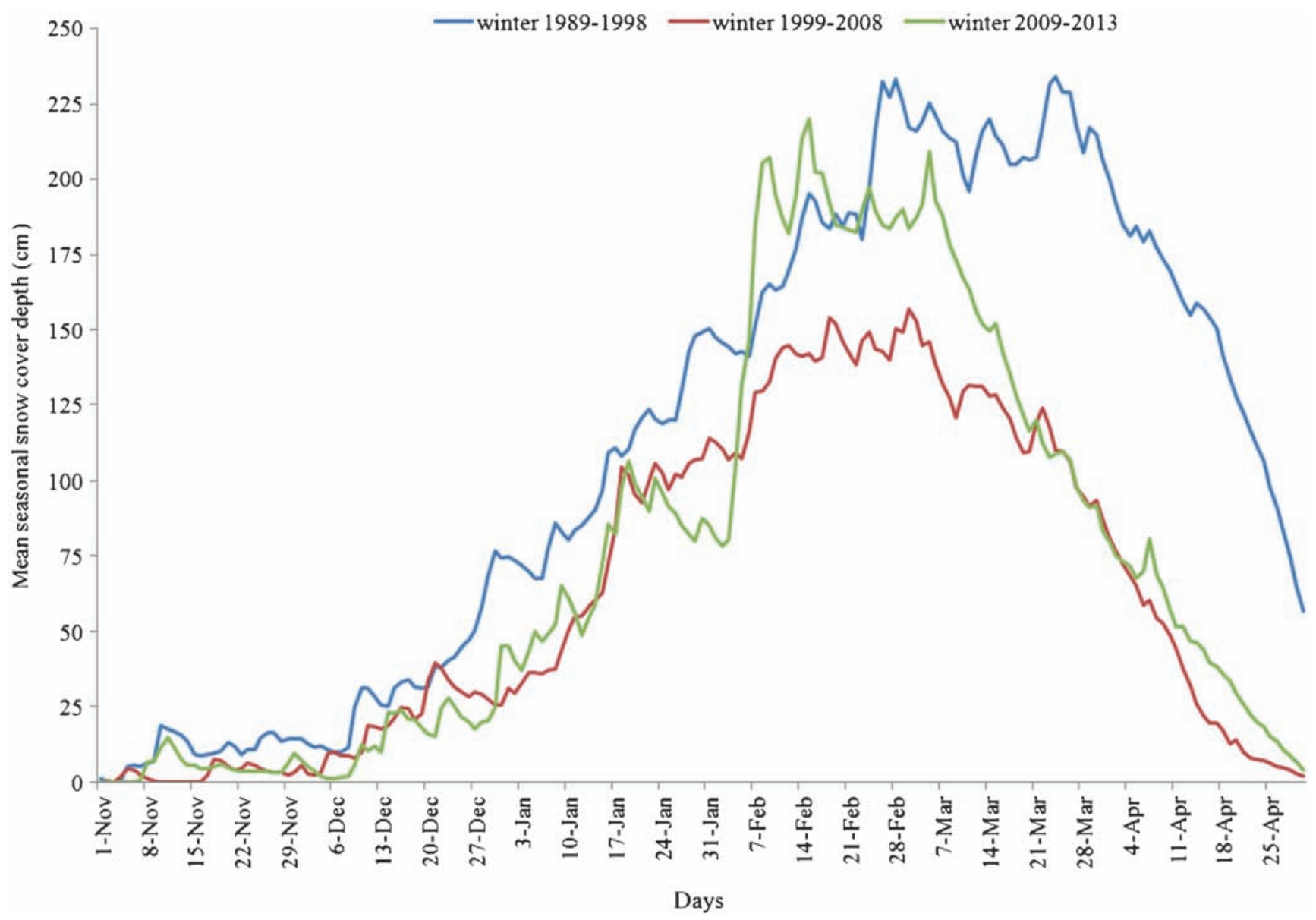

Figure 2. Mean seasonal snow cover build-up pattern at a station E in the Pir Panjal Range of the WH (Decadal: winter 1989-1998, winter 1999-2008; Five (Pent) winters: winter 2009-2013). 


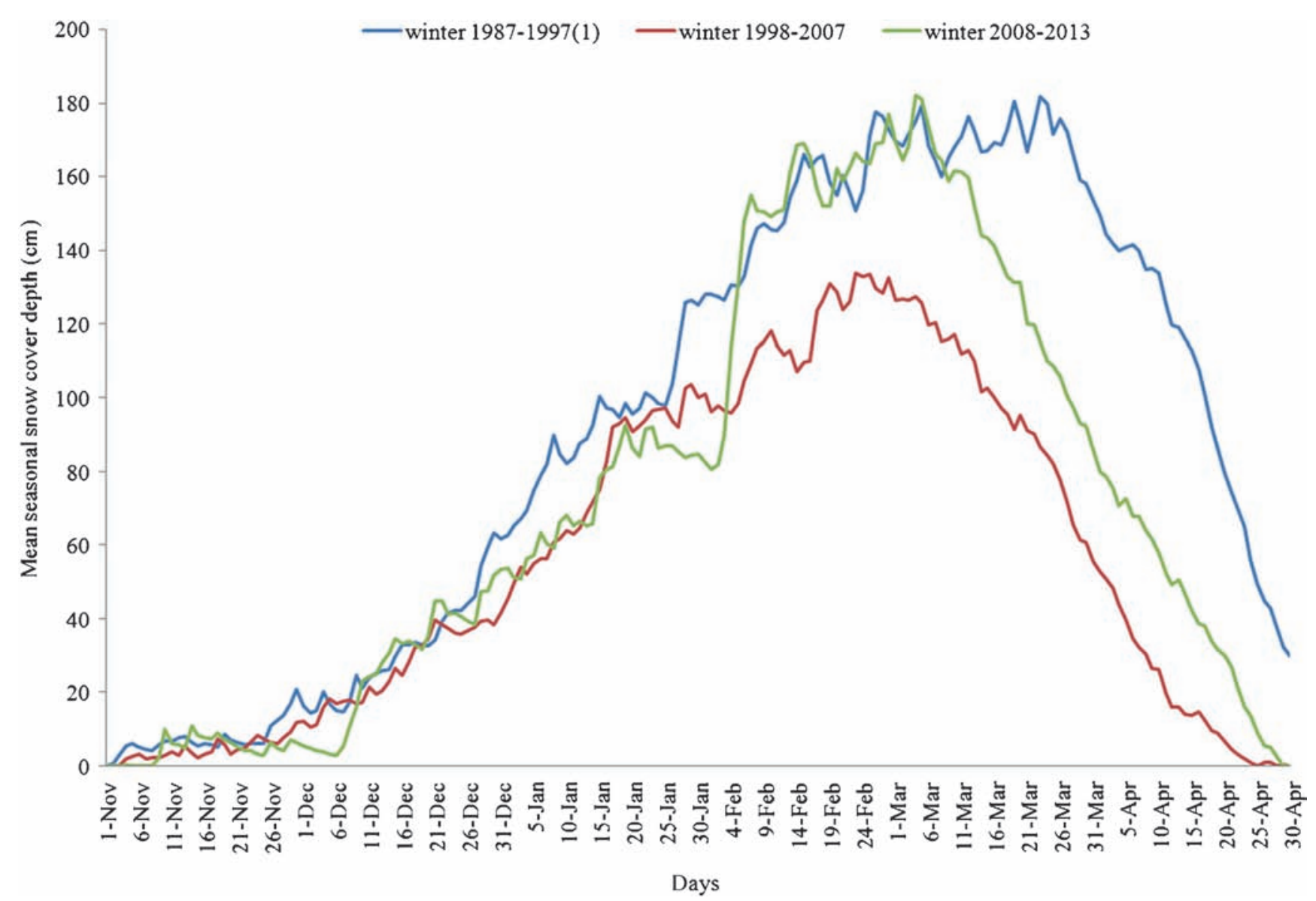

Figure 3. Mean seasonal snow cover build-up pattern at a station J in the Great Himalayan Range of the WH (number of winter with missing data is shown in bracket; Decadal: winter 1987-1997 (1), winter 1998-2007; Six winters: winter 2008-2013).

for both the stations. However, decadal snow cover build-up differs largely at each station (figures 2 and 3). This indicates that the seasonal snow cover build-up pattern over the WH has changed largely in recent decades. Changes in seasonal snow cover build-up pattern may get reflected in consistent seasonal snow cover depth and duration, delay days and early melt days of consistent seasonal snow cover, and winter period (timings) when consistent snow cover attains maximum depth (table 1 ). Hence detailed analysis of the variables listed in table 1 was carried out.

Snow cover depth data from each station is utilized to derive consistent seasonal snow cover depth and duration (length), delay days and early melt days of consistent seasonal snow cover. Consistent seasonal snow cover duration (length) is computed at each station using the following expressions:

$$
\mathrm{CSSL}_{j}=\sum_{j=1}^{n} m_{j}
$$

and

$$
m_{j}=\left(\begin{array}{ll}
1, & \operatorname{CSSD}_{j} \geq 1.0 \\
0, & \operatorname{CSSD}_{j}=0
\end{array}\right)
$$

where $j=1$ to 11 (number of stations, the suffix $j$ is followed uniquely in following definitions), $m_{j}$ equal to 1(0) represents consistent seasonal snow cover day (inconsistent/no seasonal snow cover day), $n$ and $\mathrm{CSSL}_{j}$ represent number of records and consistent seasonal snow cover length, respectively.

Delay days in build-up of consistent snow cover $\left(\mathrm{DD}^{\mathrm{cssd}}\right)$ for a winter at each station are computed using the following expression:

$$
\mathrm{DD}_{j}^{\mathrm{CSSD}}=\operatorname{Days}\left(C D_{j}-R D_{j}\right),
$$

where $\mathrm{DD}_{j}^{\mathrm{CSSD}}$ are the number of delay days, $C D_{j}$ is the start date of build-up of consistent seasonal snow cover and $R D_{j}$ is the start date of a winter season (1st November).

Early melt days of consistent seasonal snow cover $\left(E D^{\text {cssd }}\right)$ for a winter at each station were computed using the following expression:

$$
\mathrm{ED}_{j}^{\mathrm{CSSD}}=\operatorname{Days}\left(R M_{j}-C M_{j}\right),
$$

where $\mathrm{ED}_{j}^{\mathrm{CSSD}}$ are the number of early melt days, $C M_{j}$ is the melt date of consistent seasonal snow cover and $R M_{j}$ is the last date of a winter season (30th April). 
CSSD $, 25^{\text {cssd }}, 50^{\text {cssd }}, 75^{\text {cssd }}, 90^{\text {cssd }}, 95^{\text {cssd }}, \mathrm{MX}^{\text {cssd }}$, CSSL, $25^{\text {cssl }}, 50^{\text {cssl }}, 75^{\text {cssl }}, 90^{\text {cssl }}$ and $95^{\text {cssl }}$ were computed at each station to study spatial and temporal variability in consistent seasonal snow cover depth and duration over the $\mathrm{WH}$ in the past 2-3 decades (table 1). The cumulative number of days from the start date of a winter, when consistent seasonal snow cover attains maximum depth $\left(\mathrm{MX}^{\mathrm{cssl}}\right)$, were also analysed. $\mathrm{MX}^{\mathrm{cssl}}$ along with $\mathrm{DD}^{\mathrm{cssd}}$ and $\mathrm{ED}^{\text {cssd }}$ was used to get an idea of whether the consistent seasonal snow cover build-up pattern is changing in the $\mathrm{WH}$ in the recent decades.

Linear trends in CSSD, CSSL, $25^{\text {cssd }}, 50^{\text {cssd }}, 75^{\text {cssd }}$, $90^{\mathrm{css}}, 95^{\mathrm{css}}, \mathrm{MX}^{\mathrm{cssd}}, 25^{\mathrm{cssl}}, 50^{\mathrm{cssl}}, 75^{\mathrm{cssl}}, 90^{\mathrm{cssl}}, 95^{\mathrm{cssl}}$, $\mathrm{MX}^{\mathrm{cssl}}, \mathrm{DD}^{\mathrm{cssd}}$ and $\mathrm{ED}^{\mathrm{cssd}}$ were examined to see whether these variables exhibit temporal variability under global warming and indicate climate change over the WH in the recent decades (table 1 ). Linear trends in $\mathrm{DD}^{\mathrm{cssd}}, \mathrm{ED}^{\mathrm{cssd}}$ and $\mathrm{MX}^{\text {cssl }}$ were also examined to see whether there is any change in seasonal snow cover up pattern over the WH (Aguado 1990; Dettinger and Cayan 1995; Cayan 1996; Martin and Durand 1998; Bhutiyani et al. 2008). Trends in CSSD, $25^{\mathrm{cssd}}, 50^{\mathrm{cssd}}, 75^{\mathrm{cssd}}, 90^{\mathrm{cssd}}$, $95^{\mathrm{css}}$, MX ${ }^{\mathrm{cssd}}, \mathrm{CSSL}, 25^{\mathrm{cssl}}, 50^{\mathrm{cssl}}, 75^{\mathrm{cssl}}, 90^{\mathrm{cssl}}$, $95^{\mathrm{cssl}}, \mathrm{MX}^{\mathrm{cssl}}, \mathrm{DD}^{\mathrm{cssd}}$ and $\mathrm{ED}^{\mathrm{cssd}}$ at each station were examined using linear regression analysis (Pant and Rupa Kumar 1997; Bhutiyani et al. 2007; Singh et al. 2015). Standardised anomalies of CSSD, $25^{\text {cssd }}, 50^{\text {cssd }}, 75^{\text {cssd }}, 90^{\text {cssd }}, 95^{\text {cssd }}$, $\mathrm{MX}^{\mathrm{cssd}}, \mathrm{CSSL}, 25^{\mathrm{cssl}}, 50^{\mathrm{cssl}}, 75^{\mathrm{cssl}}, 90^{\mathrm{cssl}}, 95^{\mathrm{cssl}}$, $\mathrm{MX}^{\mathrm{cssl}}, \mathrm{DD}^{\mathrm{cssd}}$ and $\mathrm{ED}^{\mathrm{cssd}}$ were computed using the following expression:

$$
Z_{j}=\frac{Y_{j}}{\operatorname{std}_{j}}
$$

where $Z_{j}=$ standardized anomaly, $Y_{j}=$ anomaly from mean and $\operatorname{std}_{j}=$ standard deviation of variables listed in table 1.

Linear regression equations of the following form were developed for variables listed in table 1 at each station to examine linear trend.

$$
Z_{j}=B_{j}+C_{j} W_{j}
$$

where $Z_{j}$ is the anomaly of any variable listed in table $1, B_{j}$ and $C_{j}$ are the linear regression constant and linear regression coefficient, respectively, and $W_{j}$ is a winter season.

$C_{j}$ represents the slope of the regression line, hence the sign of $C_{j}$ indicates increasing (decreasing) trends in $Z_{j}$. A standard two tail T-test is employed to determine the statistical significance of $C_{j}$ (increasing/decreasing trend in any variable listed in table 1) (Pant and Rupa Kumar 1997; Bhutiyani et al. 2007; Dimri and Das 2011; Singh et al. 2015).

\section{Results and discussion}

\subsection{Spatial variability in consistent seasonal snow cover depth and length}

Consistent seasonal snow cover depth and length (duration) at each station were computed using available data on snow cover depth (table 2). Mean CSSD was found to lie in the range of 29.5-128.5 $\mathrm{cm}$ and $\mathrm{MX}^{\mathrm{css} d}$ was found to lie in the range of $72.7-279.8 \mathrm{~cm}$ at different stations in the WH (table 2). CSSL falls in the range 27.9-140.1 days at different stations in the WH. This indicates that CSSD and CSSL show large spatial variability in the WH (table 2). $\mathrm{DD}^{\text {cssd }}, \mathrm{ED}^{\mathrm{cssd}}$ and $\mathrm{MX}^{\mathrm{cssl}}$ also exhibit considerable spatial variability at different stations (table 2). This can be attributed to the altitude, local topography, geographic position, etc., of these stations in the WH. CSSD was found to increase with altitude up to $3000 \mathrm{~m}$ msl and was found to decrease with increasing altitude above $3000 \mathrm{~m}$ msl over different mountain ranges in the WH (table 2). This can be attributed to heavy snowfall and slower rate of increase in air temperatures (maximum temperature, minimum temperature and ambient temperature) at the lower altitude stations compared to the high altitude stations in the WH (Bhutiyani et al. 2007; Dimri and Das 2011; Singh et al. 2015). These findings indicate that consistent seasonal snow cover depth exhibits different distributional pattern with altitude in the WH. However, CSSL increases with increasing altitude in the WH (table 2). CSSD in the Great Himalayan Range was found to be less when compared to the Pir Panjal and the Shamshawari Ranges (table 2, figures 2 and 3). CSSL for the Great Himalayan Range was found to be higher than the CCSL for the Shamshawari and the Pir Panjal Ranges (table 2, figures 2 and 3 ). This shows that thin seasonal snow cover in the Great Himalayan Range persists for a longer duration as compared to the thick snow cover over the Shamshawari and Pir Panjal Ranges in the WH (table 2). Decreasing air temperature with increasing altitude and less precipitation in the Great Himalayan Range compared to the Pir Panjal and Shamshawari Ranges are probable reasons for the thin snow cover to persist for a longer duration over the Great Himalayan Range. Consistent seasonal snow cover attains a mean depth equal to $29.5 \mathrm{~cm}$ and a mean maximum depth equal to $72.7 \mathrm{~cm}$ at an altitude of around $2100 \mathrm{~m}$ in the $\mathrm{WH}$ (table 2). It attains a mean depth and a mean maximum depth in the range of 29.5-123.3 and 72.7$279.8 \mathrm{~cm}$, respectively, in the altitude range 2100 $3200 \mathrm{~m}$. Mean depth and mean maximum depth of consistent seasonal snow covers were found to be in the range of $50.4-94.1 \mathrm{~cm}$ and $137.7-237.0 \mathrm{~cm}$ 
above an altitude of $3200 \mathrm{~m}$ (table 2). These findings suggest that snow cover attains maximum depth in the altitude range $2100-3200 \mathrm{~m}$ in the WH (table 2). DD ${ }^{\text {cssd }}$ were found to be more as compared to $\mathrm{EM}^{\mathrm{cssd}}$, and $\mathrm{DD}^{\mathrm{cssd}}$ and $\mathrm{EM}^{\mathrm{cssd}}$ were found generally to decrease with increasing altitude over different mountain ranges in the $\mathrm{WH}$.

\subsection{Temporal variability in consistent seasonal, snow cover depth}

CSSD, percentiles of CSSD $\left(25^{\text {cssd }}, 50^{\text {cssd }}, 75^{\text {cssd }}\right.$, $90^{\text {cssd }}$ and $95^{\text {cssd }}$ ) and $\mathrm{MX}^{\text {cssd }}$ for each winter are computed at different stations and linear trend analysis is performed to examine their temporal variability. Most of the stations show decline in CSSD, percentiles of CSSD $\left(25^{\text {cssd }}, 50^{\text {cssd }}, 75^{\text {cssd }}\right.$, $90^{\text {cssd }}$ and $95^{\text {cssd }}$ ) and $\mathrm{MX}^{\text {cssd }}$ (table 3). Stations $\mathrm{B}$ and $\mathrm{H}$ show an increase in CSSD, percentiles of CSSD and $\mathrm{MX}^{\text {cssd }}$ (table 3) due to short data length. Eight and nine out of 11 stations were found to show a decline in CSSD and MX $\mathrm{MX}^{\text {cssd }}$, respectively, in the WH (table 3). Rate of decrease in CSSD was found to be 0.7, 0.7-2.1 and 1.0$2.4 \mathrm{~cm}$ in the Shamshawari, Pir Panjal and Great Himalayan Ranges (table 3). Stations F, K and E were found to show statistically significant declines in CSSD, percentiles of CSSD and MX ${ }^{\text {cssd }}$ (table 3 ). Rate of decrease in higher percentile values of CSSD and $\mathrm{MX}^{\mathrm{css}}$ were found to be more as compared to lower percentile values of CSSD (table 3, figure 4). These findings suggest that CSSD is decreasing. Winter extremes in terms of seasonal snow cover depth were found to be declining in the $\mathrm{WH}$, in the recent 2-3 decades, i.e., the seasonal snow cover tends to be thin. Decline in CSSD and MX ${ }^{\text {cssd }}$ at most of the stations spread across different mountain ranges in the $\mathrm{WH}$ show that $\mathrm{WH}$ as whole has undergone significant climatic changes in recent decades.

\subsection{Temporal variability in consistent seasonal, snow cover length}

CSSL and the different percentiles of CSSL $\left(25^{\mathrm{cssl}}\right.$, $50^{\mathrm{css}}, 75^{\mathrm{cssl}}, 90^{\mathrm{cssl}}$ and $\left.95^{\mathrm{css}}\right)$ for each winter were computed at different stations and linear trend analysis was performed to examine their temporal variability. Seven out of 11 stations were found to show a decrease in CSSL in the WH (table 4). However, stations with shorter data length were found to show an increase in CSSL (table 4). Percentiles of CSSL $\left(25^{\text {cssl }}, 50^{\text {cssl }}, 75^{\text {cssl }}, 90^{\text {cssl }}\right.$ and $\left.95^{\text {cssl }}\right)$ were also found to show decline in CSSL (table 4). The rate of decline in CSSL was found to be 0.3 days, 0.2-0.7 days and 0.4-1.5 days for the Shamshawari, Pir Panjal and Great Himalayan Ranges in the WH (table 4). Rate of decrease in higher percentile values of CSSL is found to be more compared to the lower percentile values (table 4). These findings suggest that consistent seasonal snow cover length (duration) is declining over the $\mathrm{WH}$ and the duration of consistent seasonal snow cover with higher snow cover depth is also declining over the WH in the recent 2-3 decades (table 4 , figures 3 and 4 ). CSSL and percentiles of CSSL at a station $J$ in the Great Himalayan Range clearly show that CSSL in the WH is decreasing in the recent decades (figure 5).

\subsection{Change in seasonal snow cover build-up pattern over the WH}

Decline in CSSD, CSSL, percentiles of CSSD and CSSL indicate that consistent seasonal snow cover

Table 3. Linear trends in CSSD, percentiles of CCSD (25 cssd $, 50^{\text {cssd }}, 75^{\text {cssd }}, 90^{\text {cssd }}$ and $95^{\text {cssd }}$ ) and MX $X^{\text {cssd }}$ at 11 stations spread across different mountain ranges over the WH (see table 1 for details; Stn = station; $W=$ winter; $(+)$ increasing trend; (-) decreasing trend; * trend statistically significant at 5\% significance level; ** trend statistically significant at $1 \%$ significance level).

\begin{tabular}{|c|c|c|c|c|c|c|c|c|}
\hline \multirow{2}{*}{$\begin{array}{l}\text { Mountain } \\
\text { range }\end{array}$} & \multirow[b]{2}{*}{ Stn } & \multicolumn{7}{|c|}{ Trends in CSSD, percentiles of CSSD and MX ${ }^{\text {cssd }}$} \\
\hline & & $\overline{\mathrm{CSSD} / \mathrm{W}}$ & $25^{\mathrm{cssd}} / \mathrm{W}$ & $50^{\mathrm{cssd}} / \mathrm{W}$ & $75^{\mathrm{cssd}} / \mathrm{W}$ & $90^{\operatorname{cssd}} / \mathrm{W}$ & $95^{\operatorname{cssd}} / \mathrm{W}$ & $\mathrm{MX}^{\mathrm{cssd}} / \mathrm{W}$ \\
\hline \multirow[t]{3}{*}{$\mathrm{S}$ range } & $\mathrm{A}$ & -0.7 & -0.1 & -1.0 & -0.4 & -0.4 & -0.4 & -0.4 \\
\hline & B & +1.8 & +0.6 & +2.3 & +3.0 & +2.7 & +2.4 & +2.1 \\
\hline & $\mathrm{C}$ & -0.7 & -0.5 & +0.4 & +0.1 & -1.3 & -1.4 & -1.7 \\
\hline \multirow[t]{3}{*}{$\mathrm{P}$ range $(\mathrm{J} \& \mathrm{~K})$} & $\mathrm{F}$ & -1.2 & $-1.4 *$ & -1.4 & -1.1 & -1.0 & -0.9 & -1.1 \\
\hline & G & -0.7 & -0.5 & -0.1 & -0.9 & -1.6 & -1.5 & -1.3 \\
\hline & $\mathrm{H}$ & +0.5 & -0.5 & +1.2 & -0.4 & +0.6 & +0.6 & +2.9 \\
\hline \multirow[t]{2}{*}{$\mathrm{G}$ range $(\mathrm{J} \& \mathrm{~K})$} & $\mathrm{J}$ & -1.0 & -1.0 & -0.9 & -1.2 & -0.9 & -1.1 & -1.6 \\
\hline & $\mathrm{K}$ & $-2.4 * *$ & $-2.1 * *$ & $-2.6 * *$ & $-2.9 * *$ & $-3.7 * *$ & $-4.1 * *$ & $-5.4 * *$ \\
\hline \multirow[t]{2}{*}{$\mathrm{P}$ range $(\mathrm{HP})$} & $\mathrm{D}$ & -0.3 & -0.3 & -0.3 & -0.3 & -0.3 & -0.4 & -0.5 \\
\hline & $\mathrm{E}$ & -2.1 & $-2.3 *$ & -2.5 & -2.0 & -2.3 & -2.7 & -2.4 \\
\hline G range $(\mathrm{HP})$ & I & +0.4 & +0.5 & +1.1 & +0.3 & -0.2 & -0.4 & -0.5 \\
\hline
\end{tabular}




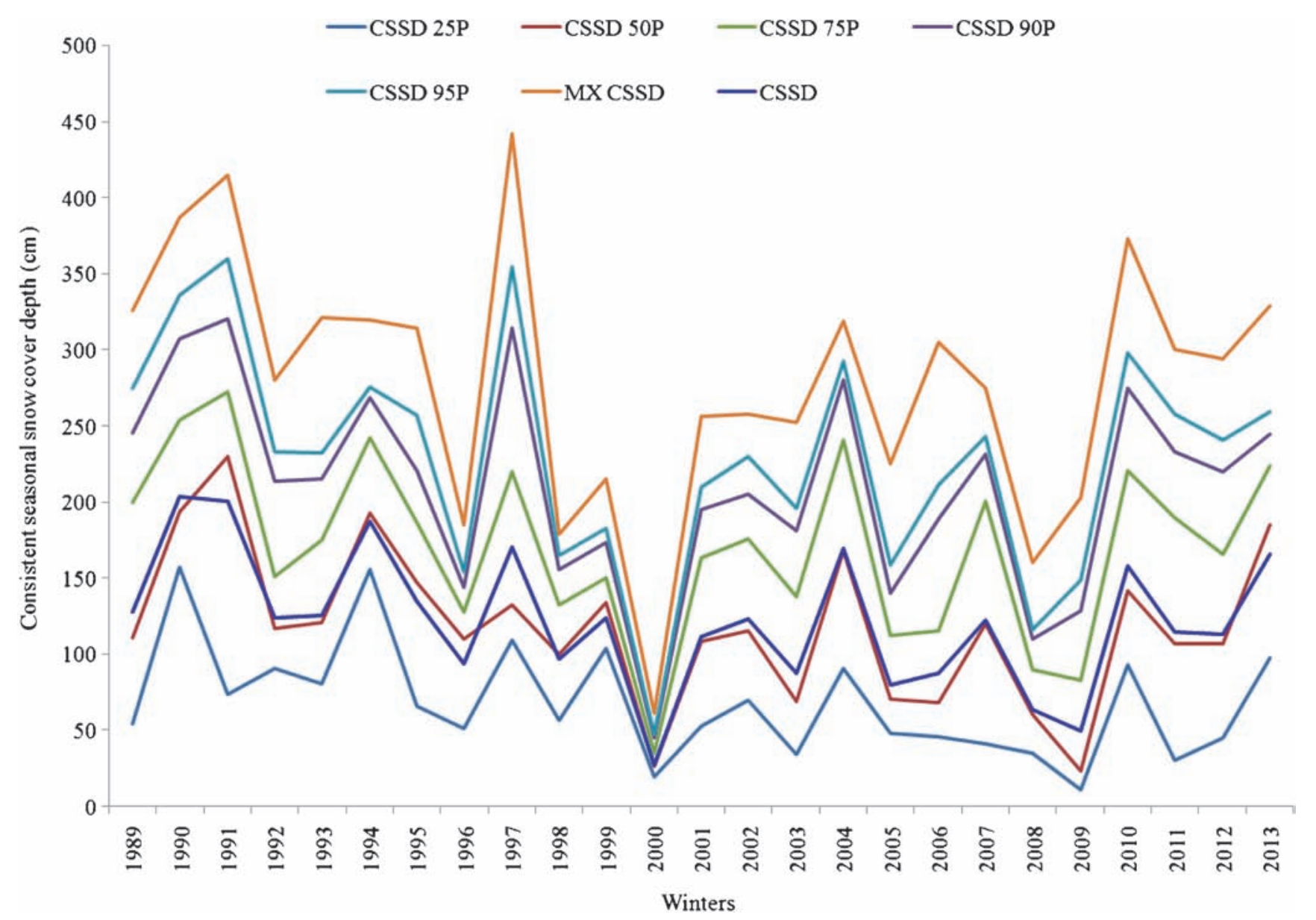

Figure 4. Temporal variability in consistent seasonal snow cover depth at a station E in the Pir Panjal Range of the WH. CSSD: consistent seasonal snow cover depth, CSSD XP: Xth percentile of CSSD (X = 25, 50, 75, 90 and 95), MXCSSD: Maximum depth of consistent seasonal snow cover.

Table 4. Linear trends in CSSL, percentiles of CCSL (25 cssl, $50^{\text {cssl }}, 75^{\text {cssl }}, 90^{\text {cssl }}$ and $\left.95^{\text {cssl }}\right), M X^{\text {cssl }}, D D^{\text {cssd }}$ and ED $D^{\text {cssd }}$ at 11 stations spread across different mountain ranges over the WH (see table 1 for details; Stn $=$ station; W $=$ winter; (+) increasing trend; (-) decreasing trend; * trend statistically significant at 5\% significance level; ** trend statistically significant at $1 \%$ significance level).

\begin{tabular}{|c|c|c|c|c|c|c|c|c|c|c|}
\hline \multirow{2}{*}{$\begin{array}{l}\text { Mountain } \\
\text { range }\end{array}$} & \multirow[b]{2}{*}{ Stn } & \multicolumn{9}{|c|}{ Trends in CSSL, percentiles of CSSL and MX ${ }^{\text {cssl }}$} \\
\hline & & CSSL/W & $\mathrm{DD}^{\mathrm{cssd}} / \mathrm{W}$ & $\mathrm{ED}^{\mathrm{cssd}} / \mathrm{W}$ & $25^{\mathrm{css} I} / \mathrm{W}$ & $50^{\mathrm{csS} I} / \mathrm{W}$ & $75^{\mathrm{css} 1} / \mathrm{W}$ & $90^{\operatorname{css} 1} / \mathrm{W}$ & $95^{\mathrm{css} 1} / \mathrm{W}$ & $\mathrm{MX}^{\mathrm{css}} / \mathrm{W}$ \\
\hline \multirow[t]{3}{*}{$\mathrm{S}$ range } & $\mathrm{A}$ & -0.3 & -0.3 & +0.5 & -0.1 & -0.2 & -0.3 & -0.4 & -0.4 & -1.1 \\
\hline & B & +0.3 & -0.2 & -0.1 & +0.1 & +0.2 & +0.3 & +0.3 & +0.3 & -0.3 \\
\hline & $\mathrm{C}$ & $+1.2 *$ & -1.2 & +0.3 & $+0.3 *$ & $+0.6 *$ & $+0.9 *$ & $+1.1 *$ & $+1.2 *$ & -0.6 \\
\hline \multirow[t]{3}{*}{$\mathrm{P}$ range $(\mathrm{J} \& \mathrm{~K})$} & $\mathrm{F}$ & +0.04 & -0.7 & $+0.6 *$ & 0.0 & 0.0 & +0.02 & +0.02 & +0.02 & -0.7 \\
\hline & G & -0.7 & +0.3 & +0.3 & -0.2 & -0.3 & -0.5 & -0.6 & -0.6 & $-1.1 *$ \\
\hline & $\mathrm{H}$ & +1.0 & -0.7 & -0.3 & +0.5 & +0.5 & +0.8 & +0.9 & +1.0 & +1.1 \\
\hline \multirow[t]{2}{*}{$\mathrm{G}$ range $(\mathrm{J} \& \mathrm{~K})$} & $\mathrm{J}$ & -0.7 & 0.0 & $+0.6 *$ & -0.2 & -0.2 & -0.4 & -0.5 & -0.6 & -0.9 \\
\hline & K & $-1.52 * *$ & +0.6 & $+0.9^{* *}$ & $-0.4 * *$ & $-0.8 * *$ & $-1.2 * *$ & $-1.4 * *$ & $-1.5 * *$ & -1.0 \\
\hline \multirow[t]{2}{*}{$\mathrm{P}$ range $(\mathrm{HP})$} & $\mathrm{D}$ & -0.2 & +0.3 & -0.1 & -0.1 & -0.1 & -0.2 & -0.2 & -0.2 & +0.5 \\
\hline & $\mathrm{E}$ & -0.5 & -0.1 & +0.6 & -0.2 & -0.3 & -0.4 & -0.5 & -0.5 & $-1.1 *$ \\
\hline $\mathrm{G}$ range $(\mathrm{HP})$ & I & -0.4 & +0.3 & +0.1 & -0.1 & -0.2 & -0.3 & -0.4 & -0.4 & -0.3 \\
\hline
\end{tabular}

build-up pattern is changing in the WH in the recent decades (figures 2 and 3 ). This may be due to a temporal shift in the starting and melting period of consistent seasonal snow cover, and temporal shift in the distribution of consistent seasonal snow cover depths for a winter. Changes in snow cover build-up pattern can be broadly identified by examining the trends in $\mathrm{DD}^{\mathrm{cssd}}$, $\mathrm{ED}^{\mathrm{cssd}}$ and 


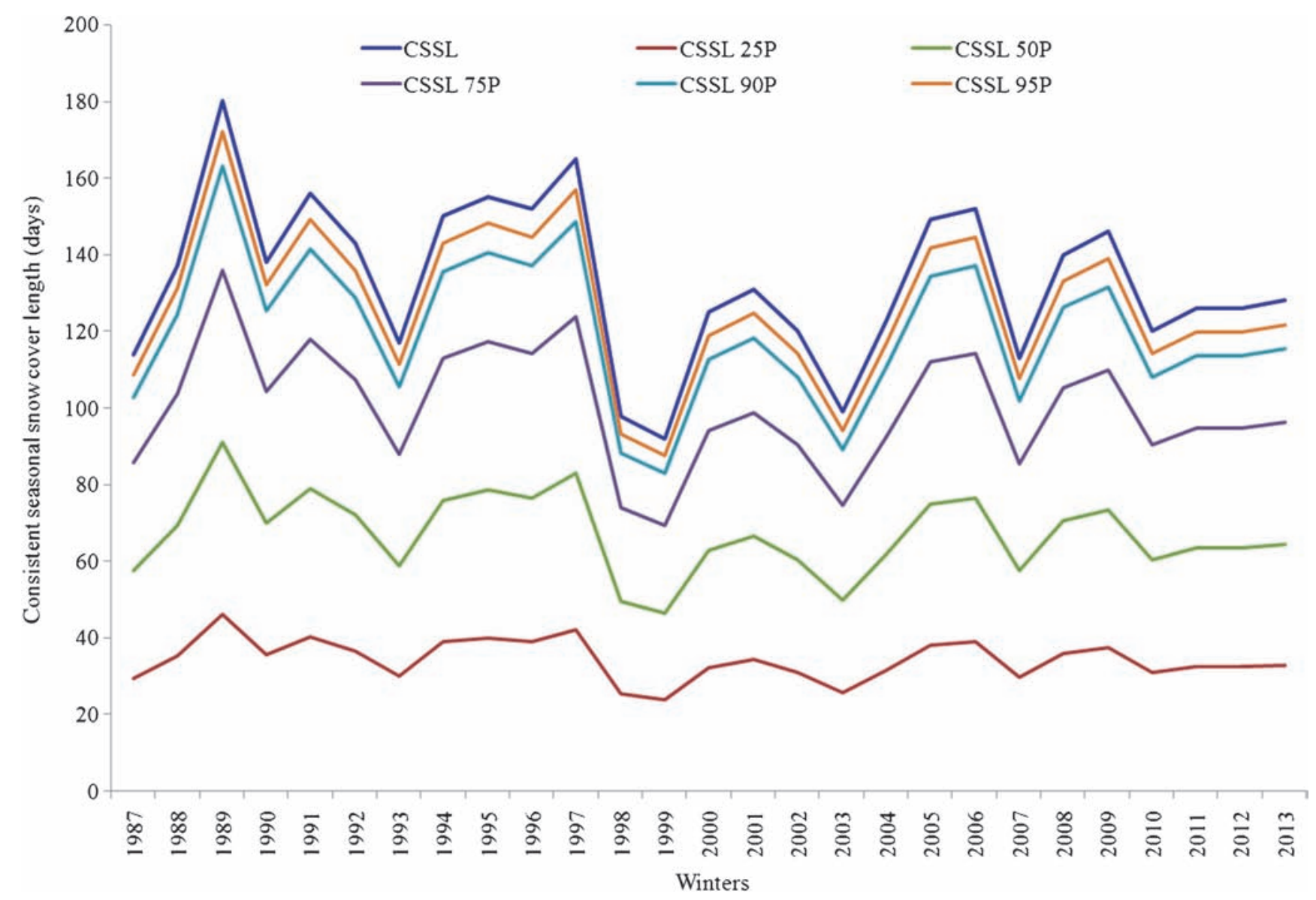

Figure 5. Temporal variability in consistent seasonal snow cover length at a station $\mathrm{J}$ in the Great Himalayan Range of the WH. CSSL: consistent seasonal snow cover length, CSSL XP: Xth percentile of consistent seasonal snow cover length $(\mathrm{X}=$ $25,50,75,90$ and 95$)$.

$\mathrm{MX}^{\mathrm{cssl}}$. Hence trends in $\mathrm{DD}^{\mathrm{cssd}}, \mathrm{ED}^{\mathrm{cssd}}$ and $\mathrm{MX}^{\mathrm{cssl}}$ were examined at each station over the WH.

Stations falling in the Shamshawari and the Pir Panjal Ranges show a decline in $\mathrm{DD}^{\text {cssd }}$ while stations in the Great Himalayan Range show an increase in $\mathrm{DD}^{\text {cssd }}$ (table 4). However, statistically significant increase (decrease) in $\mathrm{DD}^{\text {cssd }}$ was not found for at any station over the WH. Decrease (increase) in $\mathrm{DD}^{\mathrm{cssd}}$ over different mountain ranges can be attributed to the geographic position, altitude, local topography, etc., of these stations in the WH. Eight out of 11 stations showed an increase in $\mathrm{ED}^{\mathrm{css}}$ in the WH (table 4). Increase in $\mathrm{ED}^{\mathrm{cssd}}$ was found to be statistically significant at station $\mathrm{F}$ in the Pir Panjal Range and stations $\mathrm{J}$ and $\mathrm{K}$ in the Great Himalayan Range, in the WH (table 4). Most of the stations with declining $\mathrm{DD}^{\text {cssd }}$ showed an increase in $\mathrm{ED}^{\mathrm{cssd}}$ (table 4). These findings show a temporal shift in the start-up and melt period of consistent seasonal snow cover, and consistent seasonal snow cover is melting early over the $\mathrm{WH}$ in the recent decades.

The trend in $\mathrm{MX}^{\mathrm{cssl}}$ was examined at each station in the WH to know whether CSSD shows any temporal shift for a winter. $\mathrm{MX}^{\mathrm{cssl}}$ was taken for the study due to easy identification of it and high persistence in CSSD, i.e., it represents snow cover with maximum depth. Nine out of 11 stations showed a decrease in $\mathrm{MX}^{\text {cssl }}$ in the WH (table 4). Stations G and $\mathrm{E}$ in the Pir Panjal Range of the WH showed a statistically significant decline in $\mathrm{MX}^{\mathrm{cssl}}$ (table 4). This indicates that consistent seasonal snow cover depth shows temporal shift over the WH and consistent seasonal snow cover with larger depth are shifting towards early winter. Temporal shift in $\mathrm{DD}^{\mathrm{cssd}}, \mathrm{ED}^{\mathrm{cssd}}$ and $\mathrm{MX}^{\mathrm{cssl}}$ and decline in depth of consistent seasonal snow cover show that consistent seasonal snow cover build-up pattern is changing in the WH in the recent decades. Changes in snow cover build-up pattern indicate that WH has undergone considerable climate change and winter weather patterns are changing in the $\mathrm{WH}$ in the recent decades. This is because snow cover is an ultimate outcome of winter weather patterns in the WH. These findings are well supported by recent studies on WDs over the WH (Kumar et al. 2010; Madhura et al. 2014).

Madhura et al. (2014) found enhanced variability in WDs and increasing trend in heavy precipitation over the WH in recent decades. Enhancement in 
WD activities in the WH may cause precipitation to increase for a winter season. However, it is very difficult to say whether increasing WDs will enhance build-up of consistent seasonal snow cover over the WH. This is because increasing surface and mid-tropospheric air temperatures over the $\mathrm{WH} /$ Tibetan Plateau may cause reduction in solid precipitation, i.e., snow, and increase in liquid precipitation, i.e., rain over the WH (Bhutiyani et al. 2007; Liu et al. 2009; Dimri and Das 2011; Singh et al. 2015).

\section{Conclusion and limitations}

Snow cover depth data at 11 stations (2192-3800 $\mathrm{m}$ msl) spread across different mountain ranges over the WH were analysed to examine spatial and temporal variability in consistent seasonal snow cover depth and duration (length) in the past 2-3 decades. Mean consistent seasonal snow cover depth was found to be in the range of 29.5-128.5 $\mathrm{cm}$ and consistent seasonal snow cover duration was found to be in the range of 27.9-140.1 days at different stations. This shows that consistent seasonal snow cover depth and duration exhibit large spatial variability over the WH. Consistent seasonal snow cover depth and duration show a decline and the snow cover build-up pattern is changing in the WH in the recent decades. The snow cover is melting early and snow cover with higher depths is shifting towards early winter period. These findings indicate that the WH has undergone considerable climate change and winter weather patterns are changing in the WH. Changes in consistent seasonal snow cover build-up pattern in the WH may have large impacts on various socio-economic developments in the river basins of major river systems originating from the WH region, water resources, local as well as global scale weather and climate, etc.

This study was based on short length time series of snow cover depth data at 11 stations spread across different mountain ranges in the WH. Long homogeneous time series of snow cover depth in future may serve as an important indicator of climate change and it can provide a better understanding and insight on spatial and temporal variability of consistent snow cover depth and duration, and management of water resource potential of the WH.

\section{Acknowledgements}

The sincere efforts of the Scientists and Technical Staff of Snow and Avalanche Study Establishment (SASE), India, are highly acknowledged for collecting data, at remote locations, under harsh climatic conditions. Positive criticism of the work and invaluable suggestions by anonymous reviewers for improving the quality of manuscript are highly acknowledged.

\section{References}

Aguado E 1990 Elevational and latitudinal patterns of snow accumulation departures from normal in the Sierra Nevada; Theor. Appl. Climatol. 42 177-185.

Beniston M 1997 Variations of snow depth and duration in the Swiss Alps over the last 50 years: Links to changes in large-scale climatic forcings; Clim. Change 36 281-300.

Beniston M, Diaz H F and Bradley R S 1997 Climatic change at high elevation sites: An overview; Clim. Change $\mathbf{3 6}$ 233-251.

Beniston M 2003 Climatic change in mountainous regions: A review of possible impacts; Clim. Change 59 5-31.

Bhutiyani M R, Kale V S and Pawar N J 2007 Long-term trends in maximum, minimum and mean annual air temperatures across the northwestern Himalaya during the twentieth century; Clim. Change 85 159-177.

Bhutiyani M R, Kale V S and Pawar N J 2008 Changing stream flow patterns in the rivers of northwestern Himalaya: Implications of global warming in the 20th century; Curr. Sci. 95 618-626.

Bollasina M and Benedict S 2004 The role of the Himalayas and the Tibetan Plateau within the Asian Monsoon system; Bull. Am. Meteor. Soc. 85 1001-1004.

Brown R D and Braaten R O 1998 Spatial and temporal variability of Canadian monthly snow depths; Atmos. Ocean 36 37-54.

Cayan D R 1996 Interannual climate variability and snow pack in the western United States; J. Climate 9 928-948.

Chaujar R K 2009 Climate change and its impact on the Himalayan glaciers - a case study on the Chorabari glacier, Garhwal Himalaya, India; Curr. Sci. $96703-$ 708.

Dettinger M D and Cayan D R 1995 Large scale atmospheric forcing of recent trends toward early snowmelt runoff in California; J. Climate 8 606-623.

Dey B, Kathuria S N and Kumar O B 1985 Himalayan summer snow cover and withdrawal of the Indian summer monsoon; J. Clim. Appl. Meteorol. 24 865-868.

Dimri A P and Das S K 2011 Wintertime climatic trends in the western Himalayas; Clim. Change 111 775-800.

Feng S and Hu Q 2005 Regulation of Tibetan Plateau heating on variation of Indian summer monsoon in the last two millennia; Geophys. Res. Lett. 32 L02702.

Fowler H J and Archer D R 2005 Hydro-climatological variability in the Upper Indus Basin and implications for water resources; In: Regional Hydrological Impacts of Climate Change - Impact Assessment and Decision Making (eds) Wagner T et al., Proceedings of Symposium S6 held during the Seventh IAHS Scientific Assembly at Foz do lguacu, Brazil; IAHS Publ. 295 131-138.

Kang S, Xu Y, You Q, Flugel W A, Pepin N and Yao T 2010 Review of climate and cryospheric change in the Tibetan Plateau; Environ. Res. Lett. 5, doi: 10.1088/1748-9326/5/1/015101.

Kulkarni A V and Bahuguna I M 2002 Glacial retreat in the Baspa Basin, Himalayas, monitored with satellite stereo data; J. Glaciol. 48 171-172.

Kulkarni A V, Rathore B P, Mahajan S and Mathur P 2005 Alarming retreat of Parbati Glacier Beas basin, Himachal Pradesh; Curr. Sci. 88 1844-1850. 
Kulkarni A V, Bahugunna I M, Rathore B P, Singh S K, Randhawa S S, Sood R K and Dhar S 2007 Glacial retreat in Himalaya using Indian remote sensing satellite data; Curr. Sci. 92 69-74.

Kumar N, Yadav B P, Gahlot S and Singh M 2010 Winter frequency of western disturbances and precipitation indices over Himachal Pradesh, India, 1977-2007; Atmósfera 28 63-70.

Liu X, Cheng Z, Yan L and Yin Z 2009 Elevation dependency of recent and future minimum surface air temperature trends in the Tibetan Plateau and its surroundings; Global Planet. Change 68 164-174.

Madhura R K, Krishnan R, Revadekar J V, Mujumdar M and Goswami B N 2014 Changes in western disturbances over the Western Himalayas in a warming environment; Clim. Dyn. 44 1157-1168.

Martin E and Durand Y 1998 Precipitation and snow cover variability in the French Alps, In: The Impacts of Climate Change on Forests (eds) Beniston M and Innes J L, Springer-Verlag, Heidelberg/New York, pp. 81-92.

Pant G B and Rupa Kumar K 1997 Climates of South Asia: Behaviour Studies in Climatology; John Wiley and Sons, West Sussex, England, pp. 126-127.

Rechid D, Hagemann S and Jacob D 2009 Sensitivity of climate models to seasonal variability of snow-free land surface albedo; Theor. Appl. Climatol. 95 197-221.

Robinson D A, Dewey K F and Heim Jr R R 1993 Global snow cover monitoring: An update; Bull. Am. Meteor. Soc. 74 1689-1696.
Roe G H 2005 Orographic precipitation; Ann. Rev. Earth Planet. Sci. 33 645-671.

Rupper S and Roe G 2008 Glacier changes and regional climate: A mass and energy balance approach; J. Climate $215384-5401$.

Singh D, Singh A and Bhutiyani M R 2012 Depleting seasonal snow cover over northwest Himalaya; Proceeding of International Symposium on Cryosphere and Climate Change (ISCCC-2012), 2-4 April 2012, Manali, India.

Singh D, Sharma V and Juyal V 2015 Observed linear trend in few surface weather elements over the northwest Himalayas (NWH) during winter season; J. Earth Syst. Sci. 124 553-565.

Thayyen R J and Gergan J T 2009 Role of glaciers in watershed hydrology: 'Himalayan catchment' perspective; The Cryos. Discuss. 3 443-476.

Walsh J E, Tucek D R and Peterson M R 1982 Seasonal snow cover and short-term climatic fluctuations over the United States; Mon. Wea. Rev. 110 1474-1485.

Wu T W and Qian Z 2003 The relation between the Tibetan winter snow and the Asian Summer Monsoon and rainfall: An observational investigation; J. Climate 16 2038-2051.

Zhang T 2007 Perspectives on environmental study of response to climatic and land cover/land use change over the Qinghai-Tibetan Plateau: An introduction; Arct. Antarct. Alp. Res. 39 631-634.

MS received 14 March 2016; revised 20 May 2016; accepted 26 June 2016

Corresponding editor: A K SAHAI 